Original Research

\title{
Caring Efficacy and Nurse Caring Behavior in Taking Care of Critical Patients
}

\section{Lukmanulhakim Lukmanulhakim, Afriyani Afriyani, and Ani Haryani}

Faletehan University, Serang Banten Indonesia

\begin{abstract}
Introduction: Critical patients have different needs compared to patients in other general inpatient wards, so they need extra treatments from a nurse. Nurse caring behavior gived through an approach in which nurses work by improving their concern to patients. However, it is influenced by caring efficacy in which a nurse is confident to express his or her caring to patients. The aims of this study were to identify the correlation between caring efficacy with nurse caring behavior in taking care of critical patients at dr. Dradjat Prawiranegara Serang Hospital in Banten Province
\end{abstract}

Methods: This is a quantitative study with employed a correlation study. The sample size comprised 66 Nurses of ER, ICU and HCU with total sampling technique. The instruments used are CES (Caring Efficacy Scale) to measure caring efficacy and CBA (Caring Behavior Assessment) to measure nurse caring behavior. Descriptive analysis using mean, standard deviation, percentage and frequency distribution. Meanwhile, inferential analysis used Pearson's Correlation.

Results: The univariate analysis results showed the mean \pm DS score of caring behavior is $87.6 \pm 10.12$. Meanwhile, the mean \pm DS score of caring efficacy is $86.23 \pm 8.74$. Further, inferential analysis revealed a significant $(\mathrm{p}<0.000)$ and moderate correlations $(\mathrm{r}=0.448)$ between caring efficacy and nurse caring behavior.

Conclusion: Higher of nurse's caring efficacy were followed by higher of nurse's caring behavior in taking care of critical patients. Findings can be used by academic as a prospective nurse and health professionals, to implement a concept of caring efficacy to improve caring behavior. Further research can be a focus on the nursing interventions based on nurses caring behavior to strengthen and increase in taking care of critical patients.

Cite this as: Lukmanulhakim, L., Afriyani, A., Haryani, A. (2019). Caring Efficacy and Nurse Caring Behavior in Taking Care of Critical Patients. Jurnal Ners, 14(1),55-61. doi:http://dx.doi.org/10.20473/jn.v14i1.9664

\section{ARTICLE HISTORY}

Received: Sept 24, 2018

Accepted: Oct 20, 2019

\section{KEYWORDS}

caring behavior; caring efficacy; critical patients; taking care

\section{CONTACT}

Lukmanulhakim

$凶$

lukmanulhakimshodrudin@yahoo.com

$\doteq$ Faletehan University, Serang

Banten, Indonesia

\section{INTRODUCTION}

Nursing service is a form of professional service and an integral part of health service, which is based on science and nursing tips to individuals, families, groups and society either in sick or healthy condition (Ministry of Health the Republic of Indonesia, 2017). Nursing service quality greatly influences health service quality even becomes one of determining factors of the image of health service institution such as hospital. The improvement of nursing quality service is supported by nursing theories development; one of them is caring theory. Nurse caring behavior means giving nursing care service through a nurse approach of improving care to patients. Nurse attention, empathy, and concern to patients are the keys of nursing care service quality, it is very appropriate with the demand of people who expect a good and quality health service (Putri, 2014).

Watson (2008) explained that caring is a service process which is conducted by health workers especially nurses. A nurse should have caring attitude in order to give a quality nursing care; thus, patients are satisfied with health service given (Kusmiran, 2015). Nevertheless, in reality, just like what have been stated by Putra., Saleh., \& Bahar (2014), many nurses have not applied caring behavior yet. And who said that the demand of society who hopes for a good 
and quality health service. A lot of research shows that nurse caring behavior in Indonesia is still categorized low. It is previously written by Zees (2012) who obtained that $62 \%$ of nurses have low level of caring behavior. The result is also similar to Sukesi's study (2013) that $72.4 \%$ of 52 respondents show a low caring behavior.

Critical patients have different needs compared to patients in other general inpatient wards. The patients are described in unstable condition and applied with distress-causing equipment, so they need extra treatments from a nurse. The statement is in line with Jakimowich., \& Perry (2015) who said that patients in critical ward has been different form other ward. It can be seen from patients' characteristic difference in critical condition, environment, particular medical equipment, and demand of giving biological, psychological, and social treatments. Patients in critical condition possibly feel frightened, more alone, confused, and anxious. It is supported by the research findings of Lukmanulhakim., \& Syukrowardi (2018) who have identified that the majority of critical patients are in an anxious condition as evidenced by have been found 17 or most of respondents $(68.0 \%)$ in critical treatment wards are within a severe anxiety level, whereas 8 or almost half of respondents $(32.0 \%)$ are within middle anxiety level. Furthermore, Lukmanulhakim., \& Syukrowardi (2018) have also explained that beside physical support, nurses also should have ability of giving emotional, social, and spiritual support. An attitude and behavior which are able to achieve all interventions is caring.

Critical treatment wards are ones of the most chalenging, distressed-able condition, and can cause emotional problem relating to anxiety and depression for patients and the family (Rusinova, Kukal, Simek \& Cerny, 2014; Lukmanulhakim, Suryani, \& Anna, 2016). Besides, the treatment in critical treatment wards is identical with noisy effect, light, and interruption within. Noise is one of factors that cause uncomforting condition both for patients and for the family. During treatment, the issues of spiritual distress, death, family dysfunction, grief, despair, and many other emotional feelings can emerge as a part of individual copying mechanism of patients, health treatment team members, family, or next of kin. Critical sickness does not only happen from physiological alteration but also from psychosocial process, development, and spirituality. Critical sickness is also a threat for individuals and families. Being parallel to improvement of technology using in health treatment, the accompanying humanization needs become more essential. Humanization needs of health treatment parallels proof-based effective intervention more rather than plunges into tradition (Morton., Fontaine., Hudak., \& Gallo, 2011).

Watson's theory (2007), has explained that caring behavior is a manifestation of attention to others, respect for self-esteem and humanity, a commitment to prevent a deterioration, love and bonding, always together, empathy and appreciation. Furthermore,
Potter and Perry (2009) have also explained that caring behavior is an attitude that gives full attention to patients when giving nursing care. Nurse caring behavior aims to give nursing care service through an approach in which nurses work by improving their concern to patients. However, it is influenced by caring efficacy in which a nurse is confident to express his or her caring to patients and this is recognized by efficacy. According to Reid (2012), Caring efficacy is defined as nurse's confidence or ability to behave caring and to build a good relationship with patient. Caring efficacy is one's confidence to express his or her concern to develop relationship with patient and confidence means one's ability and belief to accomplish something in a situation. In addition, it is defined as one's belief to concern with decisions of achievement or development result (Coates, 1997 in Reid, 2012). According to Putra, Saleh, and Bahar (2014), nurses who work with good caring efficacy can get a satisfaction improvement for his or her job. The statement was supported by Reid's study (2011) which showed a positive correlation between nurse's caring efficacy and working satisfaction.

\section{MATERIALS AND METHODS}

\section{Study Design}

It is a quantitative research with with employed a correlation study. Correlation studies are intended to reveal correlation relationships between variables. Correlation studies refer to the tendency that variations in a variable are followed by variations in other variables. (Nursalam, 2011). This study used a cross-sectional approach. Cross-sectional design is a type of study which intends to learn correlation dynamics between risk factors and the effects through an approach, observation, or data collection at the same time (Notoatmodjo, 2010).

\section{Setting}

The data collection was conducted from May to June 2018 at critical treatment wards including Ermergency Room (ER), Intensive Care Unit (ICU), High Care Unit (HCU) of dr. Dradjat Prawiranegara Hospital in Serang City, Banten Province. Before conducting the research, the researcher did coordination with related parties, such as head room of ER, ICU, and HCU and nurses practitioner from the third wards. Then, the researcher determined the samples of the study; they are nurses practitioner of the wards. Researcher explained the research purposes, the benefits, the time, the rights of the respondents, the time contract of the research process, and the informed consent. After she got the informed consent, the respondents filled questionnaires of CES (Caring Efficacy Scale) and CBA (Caring Behavior Assessment) which the statements are scored by using Likert scale. Previously, the researcher has tested the validity and the reliability of the statement items. After getting the data form the 
questionnaires, the researcher checked it and processed it.

\section{Research Subject}

The samples of the research are all nurses practitioner of ER, ICU, and HCU of dr. Dradjat Prawiranegara Serang Hospital, there were 66 nurses practitioner by using with total sampling technique in which the sample size is same as the available population (Sugiyono, 2010).

\section{Instruments}

The instrument used for caring efficacy variable is CES (Caring Efficacy Scale) which was developed by Coates (1997) and had been used by Reid (2012). The statements within the questionnaire intends to identify nurses' confidence in their own ability. Then, the questionnaire was modified by the researcher after getting approval from previous researchers to be 26 question items based on the result of literature study relating to nurse's confidence about his or her own ability to perform caring to patients with critical condition by considering mental, psychological, physical, and spiritual aspect and technology or equipment used to take care of a patient. The questionnaire employs Likert scale with 6 choices of answer for positive statements, namely strongly disagree (score 1), disagree (score 2), somewhat disagree (score 3), somewhat agree (score 4), agree (score 5) and strongly agree (score 6). Meanwhile, Likert scale for negative statements are strongly disagree (score 6), disagree (score 5), somewhat disagree (score 4), somewhat agree (score 3), agree (score 2) and strongly agree (score 1). The questionnaire has validity values ranging from 0.497 - 0.779, and reliability test obtained alpha Cronbach of 0.812 . Meanwhile, for caring behavior variable, the researcher employed CBA (Caring Behavior Assessment) questionnaire which was developed based on Watson theory by Cronin., \& Harrison and had been modified into Indonesian language by Mulyaningsih (2013). Then, the questionnaire was remodified by the researcher after getting approval from previous researchers based on the result of literature study relating to critical patient's needs, such as by considering mental, psychological, physical, and spiritual aspect, including technology or equipment used by patients. It has 34 statement items and uses Likert scale with 4 answer options, namely always (score 4), often (score 3), seldom (score 2) and never (score 1). The validity test which employed 21 respondents obtained ranging form $0.434-0.728$ and the reliability test obtained alpha Cronbach of 0.899 .

\section{Ethical consideration}

Ethical consideration was obtained from the Committee of dr. Dradjat Prawiranegara Hospital, Serang for Human Research Subjects with the letter number of 009/TU.1218/V/2018. This is intended to avoid any negative effects for the research since she did some anticipative steps, namely accomplishing research ethics principles.

\section{Data analysis}

Before doing the statistical test analysis, the researcher did normality assumption test of the data taken through the questionnaires by employing normal curve on histogram graph, and also employed skewness score divided by standard error of skewness, in which the score used to determine data normality are from -2 to +2 (Dahlan, 2016). The result of data normality for caring efficacy variable is 1.33 after dividing skewness score with standard error. Meanwhile, the result of nurse caring behavior is 1.46 and the histogram graph of the variable is bell shape. Thus, in conclusion, the tests identified that the data is distributed normally. Descriptive analysis using mean, standard deviation, percentage and frequency distribution. Meanwhile, inferential analysis used Pearson's Correlation (Dahlan, 2016).

\section{RESULTS}

Descriptive analysis was done to see the description of characteristics nurses involved in this research. Based on table 1 above, respondents in this study are all nurses those who work from third wards of ER, ICU and HCU. The age range of nurse ranged from 24 to 47 years with an average age of 32.26 years. then also obtained the length of work range of nurses ranged from 3 to 28 years with an average length of work of 7 years. Further based on categorical data, shows most of $65 \%$ of 43 respondents are male, and with latest education background is diploma III of nursing $63 \%$ of 42 respondents.

Table 2 above, shows In this study, half of the nurses $(51.5 \%)$ were classified as having high efficacy with the average score of $92.41 \pm 8.26$. Similarly, nurses caring behavior in taking care of critical patients was found that the most of nurses $(59.0 \%)$ belonged to caring with an the average score of 89.69 \pm 8.73 .

Table 3 above, showed the results of Pearson's Product Moment correlation analysis showed statistically significant $(\mathrm{p}=0,000)$ and moderate correlation $(\mathrm{r}=0.448)$ with a positive relationship between caring efficacy and nurse caring behavior in taking care critical patients. In other words, the alternative hypothesis (Ha) is accepted, where higher caring efficacy of a nurse, it will increase of nurse caring behavior in taking care ciritical patients.

\section{DISCUSSION}

\section{Nurse's Caring Efficacy in Taking Care of Critical Patients}

Self-efficacy is defined as one's confidence in his or her ability to produce an influential performance on phenomena which influence his or her life. 
Table 1. Nurse Characteristics in Taking Care of Critical Patients $(n=66)$

\begin{tabular}{|c|c|c|}
\hline \multicolumn{3}{|l|}{ Nurse's Characteristics } \\
\hline The Mean age & \multicolumn{2}{|c|}{32,26 years } \\
\hline Age range & \multicolumn{2}{|c|}{$24-47$ years } \\
\hline The Average length of working & \multicolumn{2}{|c|}{7 years } \\
\hline Length of wroking range & \multicolumn{2}{|c|}{$3-28$ years } \\
\hline Nurse's Characteristics & $\mathbf{f}$ & $\%$ \\
\hline \multicolumn{3}{|l|}{ Sex } \\
\hline Male & 43 & $65 \%$ \\
\hline Female & 23 & $35 \%$ \\
\hline \multicolumn{3}{|l|}{ Education } \\
\hline Diploma & 42 & $63 \%$ \\
\hline Bachelor & 5 & $8 \%$ \\
\hline Professional Nurse & 19 & $29 \%$ \\
\hline
\end{tabular}

Table 2. The Mean of Nurse Caring Efficacy and Nurse Caring Behavior Score in Taking Care of Critical Patients $(n=66)$

\begin{tabular}{lccc}
\hline & Mean $\pm \mathbf{D S}$ & $\mathbf{f}$ & $\%$ \\
\hline Caring & $\mathbf{8 6 . 2 3} \pm \mathbf{8 . 7 4}$ & & \\
Efficay & $82.66 \pm 9.56$ & 32 & $48.5 \%$ \\
Low Efficacy & $92.41 \pm 8.26$ & 34 & $51.5 \%$ \\
High Efficacy & & & \\
Caring & $\mathbf{8 7 . 6} \pm \mathbf{1 0 . 1 2}$ & & \\
Behavior & $81.22 \pm 5.97$ & 27 & $41.0 \%$ \\
$\begin{array}{l}\text { Less Caring } \\
\text { Caring }\end{array}$ & $89.69 \pm 8.73$ & 39 & $59.0 \%$ \\
\hline
\end{tabular}

Table 3. The Correlation Test Result between Caring Efficacy and Nurse Caring Behavior in Taking Care of Critical Patients $(n=66)$

\begin{tabular}{|c|c|c|}
\hline & \multicolumn{2}{|c|}{$\begin{array}{c}\text { Nurse Caring Behavior in Taking } \\
\text { Care } \\
\text { Critical Patients }\end{array}$} \\
\hline & $(p)$ & (r) \\
\hline $\begin{array}{l}\text { Caring } \\
\text { Efficacy }\end{array}$ & 0.000 & 0.448 \\
\hline
\end{tabular}

Confidence can determine how someone feels, thinks, motivates and behaves. It will cause various effects through four main processes, including cognitive, motivation, affective, and selection process (Bandura, 1994). Nurses with a high caring efficacy tend to express their care easily to develop relationship with patients and to have belief of solving a problem in a particular situation. Besides, they have belief and care about decisions to one's achievement or result in the development (Coates, 1997).

The result of statistical analysis to caring efficacy of the nurses at critical treatment wards, including the ER, ICU, and HCU of dr Dradjat Prawiranegara Hospital in Serang, Banten Province showed that most of respondents have a high caring efficacy. It was identified from some statement items in the instrument that nurses with a high caring efficacy often feel confident in their ability to give medical interventions and to fulfill patient's needs. Nevertheless, the low caring efficacy was identified from statement items in which the nurses often feel unconfident to express their empathy, care, and communication. The research results surely are not detached from some factors influencing nurse's caring efficacy, namely nurse's characteristics. The results are parallel to what had been found by Putra, Saleh, \& Bahar (2014) who applied linear by linear association analysis to identify correlation among performance, caring efficacy, and respondents' characteristics. They found that sex, education background, length of working, and employment status have correlation to caring efficacy and performance. However, there is no correlation to age.

According to Bandura (1994) in Sufirmansyah (2015), efficacy refers to belief in one's ability to organize and to do a required action to manage a willbe faced situation. Thus, nurses who have a strong belief in their ability will be able to implement an excellent caring. The statement was supported by Rustika (2012), that efficacy has a very important role in daily life. People will be able to use their potentials optimally if their self efficacy support them. One of life aspects influenced by self efficacy is achievement. Efficacy in performing nurse's caring behavior is wellknown as caring efficacy. Reid (2011) stated that nurses who work with a good caring efficacy can increase satisfaction of their job. One of some efforts of building confidence, according to Bandura (1994), is Master Experience. It is defined as an experience in mastering a thing, which is directly occurred, in which the success will increase self-efficacy and the failure will decrease it. The next is Vicarious Experience which more sees others' experience in solving their problem to be an example. The last is Social Persuasion which also can be called as feedback on performance. Arousal or physical and emotional confidence also can influence one's self-efficacy level.

\section{Nurse Caring Behavior in Taking Care of Critical Patients}

Caring is an important part of nursing practice. Morrison and Burnard (2009) stated that caring in nursing as an essential interpersonal process requires nurses to do a specific role activity as a way of expressing specific emotions, including helping and serving people with special needs. They also explained nursing as a process of helping and serving, which is inseparable with caring process since at the same time they are identified to be practiced together.

The research results identified that most of nurses at the ER, ICU, and HCU have caring behavior. The presence of nurse caring behavior is possibly influenced by respondents' characteristic of 7 years working length average in which nurses often and know more patient's background which makes their caring behavior better. The result is similar with the study of Angelina, Kumaat, \& Mulyadi (2017) who stated that most of nurses $(76.7 \%)$ have caring behavior. The research result in detail showed that more than a half of respondents $(59.0 \%)$ have caring behavior. The researcher reviewed some statement 
items in CES instrument namely nurse's ability in fulfilling patient's needs, such as giving intervention suited to patient's need, facilitating patient need of worshiping, creating a protecting environment such as bed, table, and surrounding cleanliness, always ensuring patient's stability, and being able to receive either positive or negative feeling of patient such as being able to receive patient's comment.

Hidayat (2008) asserted that a professional nurse is required to implement caring behavior in conducting nursing care. Unless nurses implement a good caring behavior, such as differentiating patient, less caring and paying attention, and giving a slow and unstandardized service, they will cause harmful effects for patients, nurses, and hospital party who give nursing service. Moreover, they will create an unpleased perception in patients to nursing service, in which patients may give a bad judgment to the hospital which has given nursing service. It surely will harm the hospital party which patients' trust is decreased, so they are unwilling to visit and receive the hospital service. Finally, the amount of patients' visit to the hospital will be decreased too, then it will cause the decrease of financial income of the hospital.

Nurses are responsible to implement caring behavior. Unless it is implemented, health service and relationship between nurse and patient are less. The effort of improving caring can be done through individual, psychological, and organizational approach. Individual approach can be done by improving knowledge and skills through trainings, seminars, or formal education (Indrastuti, 2010). Organizational approach can be done through reward development plan which relates to nurses' work satisfaction and an effective leadership in nursing (Putri, 2014).

However, the study showed that some respondents (41\%) are in category of less caring. The result was shown by the assessment of nurse's communication, in which not all nurses are common to do an intensive communication with patient, relating to expressing feeling, such as expressing care and empathy. Communication is an important part in nursing care. A bad communication makes patient and the family to think that nurses' role seems not good. One of nurses' roles in critical treatment rooms is not only to give nursing service through emotional care but also to become a good communicator. Without showing a good communication to patient's family, it will be difficult to give comfort and to maintain emotional relationship with them. The proposition is similar with the statement of Lukmanulhakim., Suryani., \& Anna (2016) who argued that nurses' role is critical in some patient's family issues, such as helping them to identify their strength, to talk openly about patient's condition, and to be realistic and honest about their condition. The scholars also stated that nurses should be careful in saying their fake hope; they should express their hope and trust that patient's family are able to solve the critical situation. Furthermore, nurses should help them to find a way to communicate with nurses and discuss the uniqueness happened to patient. The statements were also supported by the study of Tumbuan, Mulyadi, \& Kallo (2017) who stated that therapeutic communication can improve patient and the family's trust to nurses.

\section{Correlation between Caring Efficacy and Nurse's Caring Behavior in Taking Care Critical Patients}

Caring efficacy is a trust of one's ability in expressing care in order to develop care relationship to patients. Health service giving based on nurse's caring behavior is able to improve health service quality. Caring implementation which is integrated to caring efficacy can improve individual health and facilitate nursing care service giving to patients. It is parallel to what had been explained by Patricia, Potter, \& Perry (2010), that nursing care becomes benchmark of service quality and patient's or family's satisfaction. Service quality becomes determiner of the image of service institution, which later can improve patient's and family's satisfaction as the service receivers.

The result of research analysis showed that caring efficacy can influence nurse's caring behavior, in which it obtained different means of caring behavior between nurses with low caring efficacy and nurses with high caring efficacy. In other words, there is a meaningful correlation between caring efficacy and nurse's caring behavior. In detail, there were 39 respondents (59\%) who showed caring behavior; however, 21 of them showed a less caring behavior (41\%). The finding surely will be risky for nursing service, which may impact on a poor nursing service. The proposition is supported by Meilani, \& fitri (2017) who stated that nurse's caring behavior can give influence on a quality service to patients.

It is important for nurses to build and apply caring efficacy into their selves. Nurses who have confidence in their ability to perform caring behavior are urgently required. It does not only relate to their selves or others but also to their job and performance in giving a quality nursing care. Coates (1997) in Reid (2012) stated that nurses who work with a good caring efficacy will be able to improve the satisfaction of their job. The statement was supported by the study of Putra, Saleh, \& Bahar (2014) about correlation among caring efficacy, work satisfaction, and nurse's performance in inpatient room. They found that a high caring efficacy can improve nurse's performance. Therefore, caring efficacy and nurse's caring behavior can give benefits to health service since the issues can increase people's trust. It also can give satisfaction to patients; thus, later the quantity of patients who come to hospital will be bigger.

\section{CONCLUSION}

The research results showed that nurses with higher of caring efficacy will be easily confident to perform care, attention, and intervention suited to patient's needs. Thus, it can improve nurse's performance in conducting their role as one of nursing worker who should improve nursing service to be better, which 
will be seen through their behavior. Nurse's caring behavior can give benefits to service as it can increase nursing care quality and achieve an optimal health service. As the result, patient's and family's satisfaction and people's trust will be achieved.

Findings of this research can be used by academic as a prospective nurse and health professionals, to implement a concept of caring efficacy to improve caring behavior in taking care of critical patients. The researcher suggested nurses in critical treatment wards to more development efforts in improving caring efficacy and caring behavior. Similarly, nurse students also need to build and understand the concept underlying caring efficacy, started from nurse education level by improving caring behavior and implementing it in field study practice. Further research can be a focus on the nursing interventions based on nurses caring behavior to strengthen and increase in taking care of critical patients

\section{REFERENCES}

Angelina, R., Kumaat, L., \& Mulyadi. (2015). Hubungan Beban Kerja Perawat dengan Caring Perawat di Instalasi Gawat Darurat Medik prof. Dr. R. D. Kandou Manado, Jurnal Keperawatan. 3(2): 1-8. Retrieved from

https://ejournal.unsrat.ac.id/index.php/jkp/arti cle/view/8029

Bandura, A. (1994). Self-efficacy. In V. S. Ramachaudran (Ed.), Encyclopedia of Human behavior (Vol. 4, pp. 71-81). New York: Academic Press. (Reprinted in H. Friedman [Ed.], Encyclopedia of mental health. San Diego: Academic Press, 1998).

Coates, C. (1997). The caring efficacy scale: Nurses' Self-reports of Caring in Practice Settings. Advanced Practice Nursing. 3(1): 53-9. Retrieved Maret 12, 2018, from : https://www.ncbi.nlm.nih.gov/pubmed/948578 1

Dahlan, M, S. (2016). Statistik Untuk Kedokteran dan Kesehatan. Edisi 6. Seri 1. Jakarta: Epidemiologi Indonesia

Depkes RI. (2008). Indikator kinerja Rumah Sakit. Retrieved Maret 12, 2018, from : http://VAww.environmentalauditing.org/Portal s/AuditFiles/AuditHospitalWasteManagement1. pdf

Depkes RI (2011). Instrumen Standar Evaluasi Penerapan Standar Asugan Keperawatan di Rumah Sakit, Jakarta : Direktorat Bina Pelayanan Keperawatan dan Keteknisan Medik Depkes RI.

Hidayat, A \& Uliyah, M, (2016). Buku Ajar Ilmu Keperawatan Dasar. Jakarta : Salemba Medika.

Indrastuti, Yani. (2010). Analisis Hubungan Perilaku Caring dan Motovasi Dengan Kinerja Perawat Pelaksana Menerapkan Prinsip Etik Keperawatan Dalam Asuhan.

Jakimowich, S., \& Perry, L. (2015). A Concept Analysis of Patient Centered Nursing In The Intensive Care
Unit. Journal of advanced Nursing, 7(71), 14991517. doi : https://doi.org/10.1111/jan.12644

Kemenkes RI (2017). Pusat Data dan Informasi Kementrian Kesehatan Republik Indonesia, Retrieved Maret 13, 2018, from : http://www.pusdatin.kemkes.go.id.

Kusmiran, Eny. (2015). Soft Skills Caring Dalam Pelayanan Keperawatan. Jakarta: Trans Info Media.

Lukmanulhakim., Suryani., \& Anna, A. (2016). The relationship between communication of nurses and level of anxiety of patient's family in emergency room dr. Dradjat Prawiranegara hospital, Serang Banten, Indonesia. International Journal of Research in Medical Sciences. 4(12). 5456-5462.

doi: http://dx.doi.org/10.18203/23206012.ijrms 20164228

Lukmanulhakim, L., \& Syukrowardi, D.A. (2018). The effects of spiritual counseling on the anxiety level of patient's family at the intensive care unit (ICU) of dr. Dradjat Prawiranegara Hospital in Serang, Banten Province, Indonesia. Belitung Nursing Journal, 4(4): 403-410. doi : http://dx.doi.org/10.33546/bnj.404

Mailani, F., \& Fitri, N. (2017). Hubungan Perilaku Caring Perawat Dengan Tingkat Kepuasan Pasien BPJS di RSUD dr. Rasidin Padang. Journal Endurance. 2(2): 203-208. doi : http://doi.org/10.22216/jen.v2i2.1882

Morrison, P. \& Burnard, P. (2009). Caring and Communicating: The Interpersonal Relationship in Nursing, 2nd Ed. Jakarta : EGC

Morton, P.G., Fontaine, D., Hudak, C. M., Gallo, B. M. (2011). Keperawatan Kritis, Pendekatan Asuhan Holistik, Ed, 8 Vol.1. Alih bahasa : Nike Budhi Subekti, S.Kp,Ns. Nurwahyu, S.Kep, Ns. Eka Anisa Mardella, S.Kep, \& Ns. Pamilih Eko Karyuni, S.Kep. Jakarta: Buku Kedokteran EGC.

Mulyaningsih, (2013). Peningkatan Perilaku Caring Melalui Kemampuan Berfikir Kritis Perawat. Jurnal Managemen Keperawatan. 1(2): 100-106. Retrieved from https://jurnal.unimus.ac.id/index.php/JMK/arti cle/view/1005

Notoatmodjo, S. (2010). Metodologi Penelitian Kesehatan (Ed. Rev.). Jakarta : Rineka Cipta.

Nursalam. (2011). Konsep dan Penerapan Metodologi Penelitian Ilmu Keperawatan. Pedoman Skripsi, Tesis dan Instrumen Penelitian Keperawata. Ed.2. Jakarta : Salemba Medika

Potter, P., \& Perry A.G. (2009). Fundamental Keperawatan. Buku 2. Edisi 7. Alih bahasa: Nggie A.F, Albar M. Jakarta: Salemba Medika

Putra, W., Saleh, A., \& Bahar, B. (2014). The Correlation of Caring and Job satisfaction with nurses performance in government hospital in palu city Central Sulawesi Province. JST Kesehatan. 4(4): 394-400. Retrieved Maret 18, $2018 . \quad$ from http://pasca.unhas.ac.id/jurnal/files/ad0bb176 700720aa1b992b9966c01c6f.pdf 
Putri, A.A. (2014). Strategi Budaya Character Caring Of Nursing. Bogor : In Media.

Reid, C. (2011). Caring Efficacy and Job Satisfaction in Australian Registered Nurses. In SSTI 41st Bienneal Convention, 29 October - 2 November 2011, Grapevine, Texas. Unpublished. Retrieved Maret 18, $2018 . \quad$ from : https://eprints.qut.edu.au/58777/

Reid, C. (2012). Examination of Relationship and Mediating Effects of Self Efficacy Locus of Control, Coping and the Practice Enviropment on Caring Efficacy and Job Satisvication in Australian Registered Nurse. Disertasi. Unpublished. Retrieved Maret 18, 2018. from : http://www.eprints.qut.edu.au/53139/1/Car ol_Reid_Thesis.pdf

Rusinova, K.R., Kukal, J., Simek,J. R.,Cerny,V. (2014). Limited Family Members/Staff Communication in Intensive Care Unit in the Czech and Slovak Republics Considerably Increases Anxiety in Patients Relatives - the DEPRESS study. BMC Psychiatry. 14(21): 2-7. doi https://doi.org/10.1186/1471-244X-14-21

Rustika, I.M. (2012). Efikasi Diri : Tinjauan Teori Albert Bandura. Buletin Psikologi. 20(2): 18-15. Retrieved from https://jurnal.ugm.ac.id/buletinpsikologi/articl e/view/11945/8799

Sugiyono. (2010). Metode Penelitian Kuantitatif Kualitatif dan R \& D. Bandung : Alfabeta.

Sukesi, N. ( 2013, Mei 16 ). Upaya Peningkatan Caring Perawat Terhadap Kepuasan Pasien di Ruang
Rawat Inap RS Permata Medika Semarang. Jurnal Managemen Keperawatan PPNI. 1(1): 15-24. Retrieved from : https://jurnal.unimus.ac.id/index.php/JMK/arti cle/view/945/997

Tumbuan, F.C., Mulyadi., Kallo, V.D. (2017). Hubungan Komunikasi Terapeutik Perawat Dengan Tingkat Kepercayaan Keluarga Pasien Di Intensive Care Unit (ICU) RSU GMIM Kalooran Amurang. Jurnal Keperawatan. 5(2): 1-6. Retrieved from : https://ejournal.unsrat.ac.id/index.php/jkp/arti cle/view/14888/14452

Watson, J. (2007). Watson's Theory of Human Caring and Subjective Living Experiences : Carative Factors/Caritas Processes as a Disciplinary Guide to the Professional Nursing Practice. Texto \& Contexto Enfermagen, 16(1): 129-35. doi: http://dx.doi.org/10.1590/S010407072007000100016

Watson, J. (2018). Social justice and human caring: A model of caring sciences as a hopeful paradigm for moral justice for humanity. Creative Nursing. 24(supl.1): 1-8. doi: https://doi.org/10.1891/1078-4535.14.2.54

Zees, R.F. (2012). Analisis Budaya Organisasi yang Berhubungan dengan Perilaku Caring Perawat Pelaksana di Ruang Rawat Inap RSUD Prof DR. H. Aloeisabue Kota Gorontalo. Journal Health and Sport. 5(2): 1-14. Retrieved from : http://ejurnal.ung.ac.id/index.php/JHS/article/ view $/ 927 / 867$ 